\title{
Out-group mating threat and disease threat increase implicit negative attitudes toward the out-group among men
}

\section{Liga Klavina, Abraham P. Buunk* and Thomas V. Pollet}

Department of Social Psychology, University of Groningen, Groningen, Netherlands

\section{Edited by:}

Debra Lieberman, University of Miami, USA

\section{Reviewed by:}

Joshua M. Tybur, University of New

Mexico, USA

Paul J. Watson, University of New

Mexico, USA

${ }^{*}$ Correspondence:

Abraham P. Buunk, Faculty of Social and Behavioral Sciences, University of

Groningen, Grote Kruisstraat 2/1, 9712

TS Groningen, Netherlands.

e-mail:a.p.buunk@rug.nl
We investigated if perceiving an out-group as a threat to one's mating opportunities enhanced the implicit negative attitudes toward that out-group. In addition, we examined the moderating effect of disease threat on the relationship between an out-group mating threat and implicit negative attitudes toward that out-group. In Experiment 1, an out-group mating threat led to stronger implicit negative out-group attitudes as measured by the Implicit Association Test, but only for men with high chronic perceived vulnerability to disease. No such effects were found among women. In Experiment 2, men in the out-group mating threat condition who were primed with disease prevalence showed significantly stronger implicit negative attitudes toward the out-group than controls. Findings are discussed with reference to the functional approach to prejudice and sex-specific motivational reactions to different out-group threats.

Keywords: out-group threat, mating competition, prejudice, disease avoidance, sex differences

\section{INTRODUCTION}

"They steal our wives and give us diseases!" - is an insult used in an anti-immigration propaganda campaign (McCullough, 2009), addressing potential concerns about out-group members competing for mating opportunities as well as the potential risk of out-group members introducing novel, and thus potentially lethal, parasites and pathogens. However, compared to economic (e.g., Butz and Yogeeswaran, 2011) and public safety issues (e.g., Dotsch et al., 2008), which are typically perceived to be associated with prejudice, competition on the mating market and the risk of disease transmission are seldom given explicit attention in psychological research on prejudice. In the present investigation, we examined if a perceived threat of out-group members to one's mating opportunities enhances negative attitudes toward the out-group, particularly among men, and especially when the infectious disease threat is salient.

\section{OUT-GROUP THREATS TO MATING OPPORTUNITIES}

Humans are very fast and eager to identify other individuals as either belonging to "us" or "them," and tend to favor the in-group and to derogate the out-group (e.g., Tajfel and Turner, 1979; Hewstone et al., 2002). While a mere categorization of the in-group vs. the out-group lays ground for a potential intergroup conflict, a perceived competition over resources is usually necessary for an actual conflict to occur. Such a conflict can trigger a whole range of intergroup processes, including prejudice, discrimination, and intergroup violence (e.g., Sherif et al., 1961; LeVine and Campbell, 1972; Stephan et al., 1998).

According to the male warrior hypothesis, such intergroup processes will be more pronounced among males due to the long history of intergroup conflict involving male rival coalitions competing over resources relevant for survival and reproduction (Van Vugt et al., 2007; Van Vugt, 2009; Van Vugt and Park, 2009). Indeed, many studies using different paradigms have shown that men are more inclined to engage in intergroup conflicts than women are.
Compared to women, men base their sense of self more on their group memberships (Baumeister and Sommer, 1997; Gabriel and Gardner, 1999), and contribute more to their in-group in the context of intergroup competition than women do (Van Vugt et al., 2007; Bugental and Beaulieu, 2009; Yuki and Yokota, 2009). Men also tend to infra-humanize out-group members more than women do (Van Vugt, 2009), and also tend to differentiate better between angry out-group male faces than women (Ackerman et al., 2006). Recently, research by Navarrete et al. (2010) has shown that sex differences in traits that are relevant to perceived threat moderate race bias. It is the aggression and dominance motivation among men, and fear of sexual coercion among women which affects reactions to a certain racial out-group.

We argue here that, especially among men, negative attitudes toward an out-group will be enhanced when the out-group is perceived to pose a mating threat. In general, males tend to compete more over mates than females do (see Trivers, 1972). In many species, females invest heavily in their offspring by going through a lengthy gestation period, a potentially risky birth and extended infant dependency (see Trivers, 1972; Symons, 1979; Daly and Wilson, 1983). On the other hand, the minimal investment in offspring a male has to provide is copulation. Consequently, males may have more potential fitness benefits from increased mating opportunities than females do, and will therefore compete more intensely with same-sex conspecifics (e.g., Buss and Schmitt, 1993). In addition, to heighten one's reproductive success and to prevent the risk of investing in other male's offspring, males in many species engage in mate guarding and in fending off potential rivals (Alexander, 1974; Buss, 2002). Research among humans suggests that males tend to behave more aggressively toward other men when a mating motive is made salient (Griskevicius et al., 2009).

Due to the reproductive importance of acquiring and guarding mates, males do not only compete with other males, but may also form coalitional alliances with other males to compete with other groups for access to females (Tooby and Cosmides, 1988; 
Kurzban and Leary, 2001; Geary et al., 2003; Van Vugt et al., 2007). Formation of male coalitional alliances is more common in species where such coalitional alliances can enhance males' chances of obtaining mates over the chances of competing for access to mates alone (Geary et al., 2003).

In line with this perspective, humans have a long history of coalitional violence and warfare, and a substantial part of these conflicts includes abduction and rape of out-group females (Wrangham and Peterson, 1996; Wrangham, 1999). Among the Yanomamö, which is a tribal community residing in the Amazon area, men who engage in intergroup warfare have greater reproductive success (Chagnon, 1988), although among the Waorani, another war-prone community in the Amazon, no relationship has been found, possibly due to their warriors having higher likelihood to be killed in revenges than the Yanomamö warriors (see Beckerman et al., 2009). In modern societies, men in street gangs have been found to have more sex partners than non-gang members (Palmer and Tilley, 1995). Underlining the role of intergroup competition over mates among males, a study by Klavina et al. (2009) showed that men perceived members of out-groups more as mating rivals and reported more negative attitudes toward them than women did.

\section{THE EFFECTS OF DISEASE THREAT IN INTERGROUP CONTEXTS}

Enhanced negative attitudes, especially among males in response to an out-group mating threat will not occur to the same extent under all circumstances. Here we propose that such negative attitudes will be stronger under conditions of a high perceived vulnerability to disease (PVD) compared to conditions of low disease vulnerability, because such conditions foster negative attitudes toward other groups. In general, recent research shows that people who either chronically or temporarily perceive themselves as vulnerable to diseases, experience more negative bias toward unfamiliar out-groups, as for example, expressed in support for stricter immigration laws (Schaller et al., 2003a; Faulkner et al., 2004; Navarrete and Fessler, 2006; Park et al., 2007).

In addition, recent research shows that population-level variations in pathogen prevalence affect cross-cultural differences contributing to prejudice toward out-groups. Negative attitudes to out-group members may help to reduce intergroup contacts when these might increase exposure to novel pathogens. For instance, transmission of pathogens can be limited by specific behavioral manifestations of collectivism, such as ethnocentrism and outgroup avoidance. Indeed, evidence shows that prevalence of pathogens correlates positively with collectivism (Fincher et al., 2008). Further, the prevalence of infectious disease has been shown to be positively associated with intrastate armed conflict, both directly and indirectly, via the negative effect of disease prevalence on national wealth (Letendre et al., 2010). Paradoxically, throughout human history, intergroup conflict required some degree of contact with out-groups, which may increase the exposure to potential pathogens. However, the long-term benefits of limiting interaction with out-group members and not having to share the same resources could outweigh the short-term costs of exposure to pathogens during intergroup conflict (Letendre et al., 2010).

Pathogen prevalence may increase mating competition particularly among males. Males have been proposed to invest less in parenting and more in mating effort when the prevalence of pathogens increases (Low, 1990; Gangestad and Simpson, 2000), which intensifies intrasexual competition. Additionally, pathogen prevalence has been suggested to increase the female preference for traits that indicate potential for high status in males (Gangestad et al., 2006), also contributing to intrasexual competition among men. There is substantial evidence that among humans worldwide variability in pathogen prevalence is associated with an increased level of polygyny and with higher numbers of women captured from other societies (Low, 1990). In polygynous societies the preference to mate with females genetically unrelated to each other may increase one's offspring's genetic variability and thus the potential chances of survival, therefore intensifying the competition for mating opportunities with out-groups. It must be noted that the immunological value of out-breeding has to be weighed against the possibility that such matings expose individuals to novel hard to beat pathogens and that there may be some level of "optimal outbreeding" (e.g., Fincher and Thornhill, 2008). Overall, pathogen prevalence may intensify intergroup competition for mates more among men than among women. Perceptions of pathogen prevalence can lower the threshold according to which out-groups are perceived as a threat to one's mating opportunities, consequently exaggerating the potential out-group mating threat and enhancing negative attitudes toward the out-group.

\section{THE PRESENT RESEARCH}

In the present research, we induced a mating threat from an outgroup by providing information that opposite sex members of the in-group are in high numbers attracted to, and marrying, members of the out-group. We expected that such a threat would enhance negative attitudes toward this group especially among men, and particularly under conditions of high pathogen salience, either in the form of dispositional perceived vulnerability to infectious diseases (Study 1) or in the form of temporal cues making vulnerability to infectious diseases salient (Study 2). To measure negative attitudes toward the out-group, we used an implicit measure, i.e., the Implicit Association Test (IAT). The IAT is designed as a measure of implicit attitudes that assesses the automatic association between a target and affective or evaluative categories (Greenwald et al., 1998). For example, in an often cited version of the IAT the association between two social categories (Black/White) and evaluative attribute (pleasant/unpleasant) are measured. The IAT task involves a quick categorization of various stimulus words according to paired concepts (e.g., Black and pleasant, or White and unpleasant; and Black and unpleasant and White and pleasant). The more closely associated the two concepts are, the faster individuals respond to them when they form a single unit. Thus, the faster individuals respond to stimulus words when Black and unpleasant represent the same response, the stronger the associations they have between the two constructs. While the IAT was initially developed to assess stable individual differences (see for review, Schnabel et al., 2008), it is often also used as a measure to assess changes in the strengths of associations depending on contextual cues (e.g., Schaller et al., 2003b). For example, cues that make disease threats salient increase the association between out-groups and negative categories (Faulkner et al., 2004). The IAT is less prone to some of the problems that explicit measures of negative attitudes toward the out-group have, i.e., self-presentation concerns 
which lead to masking one's true attitudes. In the present context, it seemed particularly appropriate to use IAT instead of explicit measures because openly expressing negative reactions to outgroup members engaging in romantic relationships with in-group members is socially undesirable in the context where this study was conducted. The IAT has been criticized for its validity as a measure of stable trait prejudice, as it may simply reflect associations that a person has been exposed to rather than personal endorsement of these associations (e.g., Karpinski and Hilton, 2001). However, this criticism does not apply to the present studies, as the IAT is used as a dependent measure to assess the effects of an experimental manipulation and not as an individual difference measure.

\section{STUDY 1 \\ MATERIALS AND METHODS \\ Sample}

One hundred forty-seven participants (39 men, 108 women), enrolled in a large Dutch university, participated in the study as part of course requirements fulfillment. The study took place in separate cubicles and participants completed all the tasks individually on computers. Students who indicated that they had a different nationality than Dutch were excluded from the final sample, which resulted in a sample of 32 men and 81 women (age: $M=20.3$ years, $\mathrm{SD}=3.23$ ).

\section{Procedure}

Participants answered demographic questions, and then completed several additional questionnaires. Participants completed the PVD questionnaire (Park et al., 2003). This measure specifically assesses to what extent individuals perceive themselves as vulnerable to disease. It includes items that assess the perceived susceptibility to illness (e.g., "I have a history of susceptibility to infectious disease") and the aversion to germ transmission (e.g. "I prefer to wash my hands pretty soon after shaking someone's hand"). Cronbach's alphas range from 0.70 to 0.80 (Faulkner et al., 2004). The reliability of the scale in this study was moderate (Cronbach's alpha $=0.66$ ). The germ aversion had lower reliability (alpha $=0.56$ ), whereas the perceived infectability had higher reliability $($ alpha $=0.83)$ than the PVD scale.

In a previous study we investigated which out-group nationalities are perceived as posing the highest mating threat and what characteristics contribute to the perceived threat. We found that Italians were perceived as the out-group evoking the highest levels of jealousy due to their high status and attractiveness (Klavina et al., 2009). Based on these findings we decided to use Italians as the target out-group. Out-group mating threat was induced by a bogus newspaper article. Male participants read a bogus article, which contained interviews with several Dutch women praising Italian men and expressing willingness to engage in relationships with them. Additionally, the bogus article included a graph illustrating a steep increase in the number of marriages between Dutch women and Italian men. In the version for female participants the only difference was that Dutch men were praising Italian women, and a steep increase between Dutch men and Italian women was shown. Male participants in the control condition read a similar bogus article, but with the difference that Dutch women after having had experience with Italians described them as not desirable as mates. Female participants read comments of Dutch men being unwilling to have Italian women as mates. The graph illustrated that despite the increasing integration and travel in the European Union, there has been no increase in marriages between Dutch women and Italian men, in the male version, and between Dutch men and Italian women, in the female version. It should be noted that in the mating threat condition, no explicit mention was being made of an influx of Italians or that these marriages led to residency in the Netherlands.

\section{Implicit association task}

In this study the IAT task was introduced to participants as a reaction time test, and participants were instructed to react to stimulus words as fast and as accurate as possible. We used two types of stimulus words, namely words indicating valence (positive and negative words), and names indicating in-group and out-group members (Italian and Dutch person names). Participants were presented with a stimulus word in the middle of the screen and were asked to indicate if it belonged to either the positive or the negative words in the case of the valence words; or to either the Italian or the Dutch names in the case of the in-group and out-group names as quickly and accurately as possible. They could react to the stimuli by pressing keys on the computer keyboard, a right-key to indicate that the stimuli belong to the category displayed on the right upper corner and the left-key for the category in the left upper corner. An example of a screenshot of the IAT task can be found in Figure A1 in Appendix. The M key was used for the right category and the $\mathrm{Z}$ key for the left category. The IAT measure consisted of seven blocks, of which three are practice blocks, and four are test blocks. Participants were presented with the same-sex names, i.e., women reacted to female names and men reacted to male names. We used five typical Italian person names (e.g., "Marcello," for males; "Luciana," for females) and five typical Dutch names (e.g., "Jeroen" for males; "Willemien" for females); and five positive words (e.g., "love") and five negative words (e.g., "hate"). The complete list of words can be found in Table A1 in Appendix. The person names were chosen from a list of most popular names in both countries, and two independent language experts chose names that are typical for both countries and are not used internationally. The length of each word was matched as much as possible. In two of the critical blocks Dutch names were paired with positive words and Italian names with negative words and in the other two critical blocks Dutch names were paired with negative words and Italian names with positive words.

The measure of negative implicit bias ( $D$-score) was calculated following an algorithm described by Greenwald et al. (2003). The procedure involves subtracting the mean reaction times in blocks where Italians were paired with positive words (and the Dutch with negative category) from the ones where Italians were paired with negative words (and the Dutch with positive category) and dividing this mean difference by a pooled SD across the blocks (for details see, Greenwald et al., 2003). The error trials were replaced with the block mean summed with a 600 -ms penalty, and reaction latencies longer than $10,000 \mathrm{~ms}$ were eliminated. In line with the procedure used by Greenwald et al. (2003), participants with more than $10 \%$ of reaction latencies shorter than $300 \mathrm{~ms}$ were excluded from analysis. Relatively longer reaction times on trials in which 
Italian same-sex names are paired with the positive category and relatively shorter reaction times on trials in which Italian same-sex names were paired with negative category indicate stronger implicit negative attitudes toward the Italian same-sex members. A higher $D$-score indicates relatively more implicit association of Italians with negative categories or more implicit association of Dutch with positive categories. A $D$-score of 0 or close to 0 indicates no implicit associations as the reaction times in the two types of critical blocks are equal or almost equal. A negative $D$-score indicates a relatively stronger implicit association of the Italians and the positive category, thus more positive attitudes toward the out-group, whereas a positive $D$-score means relatively strong negative association of Italians and the negative category, thus more negative attitudes toward the out-group.

\section{RESULTS AND DISCUSSION}

First, an ordinary least squares regression analysis was run to identify a possible three-way interaction between sex, out-group mating threat and PVD as independent predictors and the D-score as dependent variable. The categorical variables (sex and out-group mating threat) were dummy-coded, and the continuous variable (PVD) was centered. The results showed a significant three-way interaction between the three predictors, $\beta=-2.31, t(105)=-3.14$, $p<0.01, R^{2}=0.11$, adjusted $R^{2}=0.08$. To further investigate the three-way interaction, we ran separate analyses for men and for women. There were no main effects of mating threat and PVD, neither among male participants nor female participants. However, there was a significant interaction between out-group mating threat and PVD among men $\beta=0.47, t(28)=2.72, p<0.01, R^{2}=0.22$, adjusted $R^{2}=0.21$. The interaction effect was not significant among women $\beta=-0.08, t(76)=-0.68, p=0.507, R^{2}=0.02$, adjusted $R^{2}=0.01$. As predicted, male participants who were high in PVD reacted to the out-group mating threat with more negative attitudes toward that out-group than male participants who were low in PVD (see Figure 1).

In addition, we analyzed the effects of both subscales of the PVD scale. There was no significant interaction between out-group mating threat and germ aversion neither among men $(\beta=0.10, t(28)=0.50$, $p=0.62, R^{2}=0.02$, adjusted $\left.R^{2}=-0.08\right)$ nor women $(\beta=-0.05$, $t(76)=-0.42, p=0.67, R^{2}=0.05$, adjusted $\left.R^{2}=0.008\right)$. The interac-

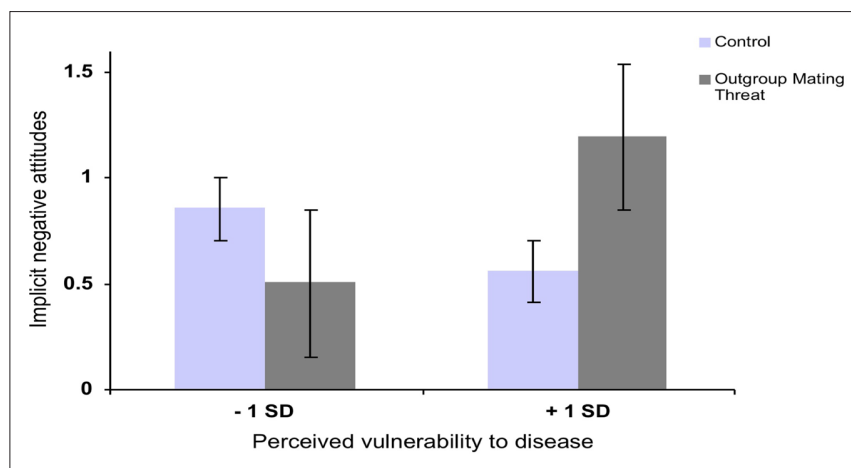

FIGURE 1 | Implicit negative attitudes as a function of experimentally manipulated out-group mating threat and dispositional perceived vulnerability to disease among men (error bars indicate standard error). tion between out-group mating threat and perceived infectability showed a statistical trend among men $(\beta=0.35, t(28)=1.73, p=0.09$, $R^{2}=0.11$, adjusted $\left.R^{2}=0.01\right)$ but was not significant among women $\left(\beta=-0.0, t(76)=-0.42, p=0.67, R^{2}=0.02\right.$, adjusted $\left.R^{2}=-0.02\right)$. As the overall PVD scale seems to be better predictor, we used this variable in further analyses rather than the subscales.

A simple slopes analysis computed at $M \pm 1 \mathrm{SD}$ showed that among male participants who were high in PVD, the effect of mating threat was significant $\beta=0.64, t(27)=2.51, p=0.02$, whereas among male participants who were low in PVD the effect of mating threat, did not reach statistical significance $\beta=-0.36, t(76)=-1.48, p=0.15$.

These results show that, as predicted, men, but not women, who perceive themselves as especially vulnerable to disease react with more implicit negative attitudes toward same-sex out-group members that pose a mating threat than men who did not perceive themselves as vulnerable to disease. As individual differences in PVD may be confounded with other variables, in Study 2 we used an experimental design to investigate if among men the temporary salience of pathogen prevalence would elicit the same reaction to mating threat as in Study 1.

\section{STUDY 2 \\ MATERIALS AND METHODS \\ Sample}

The participants were 91 men (age $M=21.41$ years, $\mathrm{SD}=3.34$ years) studying at a large Dutch university. The sample consisted of psychology students who took part in the study as part of course requirements fulfillment and non-psychology students who were paid five Euros for their participation. Students who indicated that their parents were born outside of the Netherlands (in total 10 participants) were excluded from analysis. The study took place in separate cubicles and participants completed all the tasks individually on computers.

\section{Design}

The study had a $2 \times 2$ factorial between-subjects design: (high outgroup mating threat vs. low out-group mating threat $) \times($ disease salience vs. accident salience).

\section{Procedure}

Participants first answered basic demographic questions, and then completed several additional questionnaires. To prime the salience of infectious diseases, we used a series of pictures used in prior studies (Faulkner et al., 2004). In the disease salience condition participants viewed nine pictures that illustrated the presence of pathogens in everyday life situations and the high risk of infection, like the schematic illustration of contamination with tuberculosis, the stages of anthrax contamination, and drawings of germs in the kitchen. The pictures included a short description of the illustrated process. Pictures were centered on the screen with size adjusted to achieve the best resolution. The images were on average $12 \mathrm{~cm}$ height and $10 \mathrm{~cm}$ width. Participants viewed the pictures twice, after the first viewing session they were asked to evaluate how educational they thought the pictures were, and after the second viewing session they indicated their general impression about the pictures. The exposure to each picture lasted for approximately 1-2 min. In the control condition the same procedure was carried out with 
pictures illustrating everyday dangerous situations, like, burning one's finger with an iron, or not paying attention to traffic signs, to induce a feeling of danger unrelated to disease threat.

After viewing the images, the participants were presented with the stimuli from Study 1 (bogus news paper study on intermarriage between Italians and Dutch: either documenting that Dutch women like and intermarry Italians or that there was no increase in intermarriage and liking.).The out-group mating threat manipulation was thus identical to the one in Study 1. Directly after the manipulations participants completed the same IAT task as in Study 1. Scores were calculated in the same way as described for Study 1.

\section{RESULTS}

As the results from Study 1 showed effects of PVD and out-group mating threat, we focused on the theoretically relevant contrast - the difference between the critical condition in which both outgroup mating threat and disease threat are salient, and the other three conditions. We tested an orthogonal contrast code $+3,-1,-1$, -1 , with the critical condition coded as +3 , and the other conditions as -1 . In line with our predictions, the results showed that men who perceived an out-group mating threat and for whom infectious disease was made salient showed significantly more negative attitudes toward the out-group than men in the other conditions $\beta=0.24, t(68)=2.04, p<0.05, R^{2}=0.06$ (see Figure 2).

Thus, male participants confronted with a high mating threat who also were primed to perceive a high disease threat showed more negative attitudes toward the out-group than participants from the other three conditions ("high out-group mating threat and accident threat"; "low out-group mating threat and high disease threat" and "low out-group mating threat and accident threat").

In addition to comparing the critical condition to pooled data from all the other conditions, we investigated the effect of mating threat within the high disease salience condition. An ordinary least squares regression analysis showed that among men in the high disease threat salience condition, there was a significant positive effect of out-group mating threat $\beta=0.31, t(39)=2.00, p=0.05$, adjusted $R^{2}=0.10$. When disease threat was not salient (the accident condition), the difference between the mating threat and control condition was not significant $\beta=0.07, t(30)=0.30, p=0.77$, adjusted $R^{2}=0.003$.

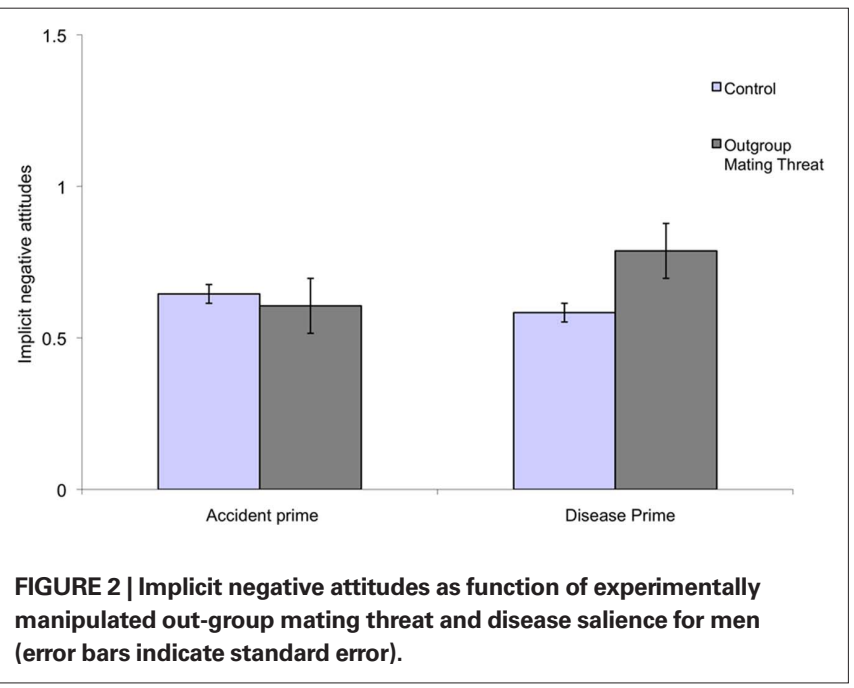

\section{GENERAL DISCUSSION}

The results from both studies are in line with our predictions. Among men, but not among women, a mating threat from an outgroup enhanced the implicit negative attitudes toward that group (Study 1). As predicted, this was only found among men who tended to perceive themselves as being vulnerable to infectious diseases. In Study 1 we showed that men who perceived themselves as dispositionally vulnerable to disease showed the highest level of implicit negative attitudes toward an out-group that presented a mating threat. Study 2 corroborated this result by showing that men, for whom disease threat was temporarily made salient, displayed the highest level of implicit negative attitudes toward an out-group that presented a mating threat. Thus, it appears that in this case the threat of potentially decreasing mating opportunities due to Italians competing for in-group women does not affect implicit attitudes toward this out-group, as we did not find a main effect of mating threat. It is the perceptions of Italians competing for mating competition in combination with heightened disease concerns that result in an increase of implicit negative attitudes toward Italian male targets among men.

From a theoretical point of view, the present research demonstrates the relevance of considering sex differences that are often neglected in social psychological research on intergroup behavior. Such sex differences are also manifest in, for example, research on social dominance orientation, which shows that men consistently score higher on a scale that assesses individual differences in outgroup discrimination and preference for hierarchy (Pratto et al., 1994; Sidanius and Pratto, 1999), and in research showing responses to a coalitional threat to be more amplified among men (e.g., Van Vugt et al., 2007; Bugental and Beaulieu, 2009; Van Vugt, 2009; Van Vugt and Park, 2009; Yuki and Yokota, 2009). In general, the present results fit in a broader framework of the functional flexibility of social behavior (Cottrell and Neuberg, 2005; Neuberg and Cottrell, 2008) as they illustrate that the reactions to an out-group mating threat may be most intensely negative when they are the most adaptive. That is, as men are typically involved in intergroup rivalry (e.g., Tooby and Cosmides, 1988), and as men are competing for mating opportunities more than women are, being vigilant toward an out-group mating threat may be a more functional response for men than for women. However, this response did not appear to occur when there was no salient threat of a disease: it occurred only when men perceived themselves to be highly vulnerable to disease. The combined disease and mating threat may have resulted in a concern that novel pathogens will be introduced to the in-group, i.e., via intimate contact with in-group women.

Previous research has shown that being concerned about disease threats in one's environment may increase prejudice toward unknown out-groups (Schaller et al., 2003a; Faulkner et al., 2004). In addition, population level analyses have shown that prevalence of infectious disease is associated with collectivism (Fincher et al., 2008), potentially leading to ethnocentrism and avoidance of outgroup members. Especially relevant is the finding that disease prevalence is positively associated with intergroup conflict (Letendre et al., 2010). Our findings extend this line of research by showing that disease concerns evoke more negative reactions toward an outgroup that poses a mating threat, and that this effect is especially present among men. 
We do not suggest that women are resistant and unresponsive toward out-group threats. For women, however, the adaptive problem appears quite different. Women definitely can be harmed during intergroup conflict in different kind of ways, for example, they can be molested, kidnaped, and raped (Navarrete et al., 2010). But, the source of potential violence is typically men, not other women (Navarrete et al., 2009). The competition among women tends to be more verbal rather than physical and it tends to take place on the intragroup level rather than intergroup level (Geary et al., 2003; Griskevicius et al., 2009). When the out-group threat is a mating threat constituted by out-group women, women will not react with the same level of negative bias as men would. Additionally, a contact with an out-group, given that it is peaceful, may for women even offer opportunities, as for example moving to another, potentially higher status group, or potential even obtaining good genes from sexual contact with out-group men.

The present research has several limitations, and suggests important issues for future research. One potential limitation is that the mating threat may have made salient the concern over an increased risk of in-group infection with novel out-group pathogens. We aimed to avoid this by matching the exposure to the out-group in the control condition. Both the mating threat condition and the control condition imply intergroup interactions, as the control condition includes scenarios where women describe their experience with Italian men as unpleasant and undesirable. Moreover, the higher rate of intermarriages does not necessarily mean a higher influx of the out-group members, as the intermarrying in-group members may be emigrating. Nevertheless, the mating threat condition may, given the closer contact with the out-group members, indeed imply a greater possibility for disease transmission. This seems in itself not a problem, because it still is the case that the effect of the mating threat is enhanced by the disease threat. In future studies this phenomenon could be investigated further by evoking mating threat from an out-group and varying the perceptions of contact between the both groups, thereby allowing to control for the perceived exposure to potential out-group pathogens.

A second potential limitation is that we used an out-group of roughly the same socio-economic status as the in-group. Moreover, in this context, behavioral immunity considerations

\section{REFERENCES}

Ackerman, J. M., Shapiro, J. R., Neuberg, S. L., Kenrick, D. T., Becker, D. V., and Griskevicius, V. (2006). They all look the same to me (unless they're angry). Psychol. Sci. 17, 836-840.

Alexander, R. (1974). The evolution of social behavior. Annu. Rev. Ecol. Syst. 5, 325-383.

Baumeister, R. F., and Sommer, K. L. (1997). What do men want? Gender differences and two spheres of belongingness: comment on Cross and Madson (1997). Psychol. Bull. 122, 38-44.

Beckerman, S., Erickson, P. I., Yost, J., Regalado, J., Jaramillo, L., Sparks, C., Iromenga, M., and Long, K. (2009). Life histories, blood revenge, and reproductive success among the
Waorani of Ecuador. Proc. Natl. Acad. Sci. U.S.A. 106, 8134-8139.

Bugental, D. B., and Beaulieu, D.A. (2009). Sex differences in response to coalitional threat. Evol. Hum. Behav. 30, 238-243.

Buss, D. M. (2002). Human mate guarding. Neuro Endocrinol. Lett. 23, 23-29.

Buss, D. M., and Schmitt, D. P. (1993). Sexual strategies theory: an evolutionary perspective on human mating. Psychol. Rev. 100, 204-232.

Butz, D.A., and Yogeeswaran, K. (2011).A new threat in the air: macroeconomic threat increases prejudice against Asian Americans. J. Exp. Soc. Psychol. 47, 22-27.

Chagnon, N. A. (1988). Life histories, blood revenge, and warfare in a tribal population. Science 239, 985-992.

may have little relevance to out-group attitudes because the groups already share most pathogen strains, and the out-group is, overall, relatively healthy (and Western). In the case of outgroups with a lower socio-economic background concerns about contagion might me more relevant as these groups typically have worse access to public health. However, given the low potential infectious threat, having Italians as an out-group in our study may make our results even more noteworthy. Another potential limitation is that other potential out-group threats, for example to public safety, were not assessed as the focus of this article was on an out-group mating threat. For a more complete understanding of the specific reactions evoked by this type of threat, it should be compared to other types of out-group threat, e.g., an economic threat or a territorial threat (see Cottrell and Neuberg, 2005). Future research is necessary to determine the relative importance of mating threat compared to other threats for attitudes toward specific out-groups.

Furthermore, we did not examine the potential effects of opposite sex out-group members. This could have led to potentially interesting results, especially among women. Therefore, an interesting future direction is the investigation of sex differences when people are presented with opposite sex targets who are mating with members of the in-group. In this case, the pattern of sex differences could be opposite to the findings from our studies - women who perceive themselves as vulnerable to diseases might react with more prejudice to out-group men as they are a more relevant threat, via sexual coercion than out-group women. Women who perceive themselves as highly vulnerable to disease may be more vigilant toward threat of sexual coercion, which indeed has been shown to motivate women's bias toward out-group men (Navarrete et al., 2010).

To conclude, the present research offers a potential explanation as to why an anti-immigration propaganda slogan, like "They steal our wives and give us diseases?" might be effective - arguing that out-group males are after in-group's women combined with the salience of disease prevalence may foster prejudice.

\section{ACKNOWLEDGMENT}

This research was funded in part by the Netherlands Royal Academy of Arts and Sciences.

Cottrell, C., and Neuberg, S. L. (2005) Different emotional reactions to different groups: a socio-functional threat-based approach to prejudice. J. Pers. Soc. Psychol. 88, 770-789.

Daly, M., and Wilson, M. (1983). Sex, Evolution, and Behavior, 2nd Edn. Boston: PWS Publishers.

Dotsch, R., Wigboldus, H. J., Langner, O., and van Knippenberg,A. (2008). Ethnic out-group faces are biased in the prejudiced mind. Psychol. Sci. 19, 978-980.

Faulkner, J., Schaller, M., Park, J. H., and Duncan, L.A. (2004). Evolved diseaseavoidance mechanisms and contemporary xenophobic attitudes. Group Process. Intergroup Relat. 7, 333-353.

Fincher, C. L., and Thornhill, R. (2008) Assortive sociality, limited dispersal, infectious disease, and the genesis of global pattern of religious diversity. Proc. R. Soc. Lond. B Biol. Sci. 275, 2587-2594. Fincher, C. L., Thornhill, R., Murray, D. R., and Schaller, M. (2008). Pathogen prevalence predicts human crosscultural variability in individualism/ collectivism. Proc. R. Soc. Lond. B Biol. Sci. 275, 1279-1285.

Gabriel, S., and Gardner, W.L. (1999). Are there "his" and "her" types of interdependence? The implications of gender differences in collective and relational interdependence for affect, behavior, and cognition. J. Pers. Soc. Psychol. 75, 642-655.

Gangestad, S. G., Haselton, M. G., and Buss, D.M. (2006). Evolutionary foundations of cultural variation: evoked culture and mate preferences. Psychol. Inq. 17, 75-95. 
Gangestad, S. W., and Simpson, J. A. (2000). On the evolutionary psychology of human mating: trade-offs and strategic pluralism. Behav. Brain Sci. 23, 573-587.

Geary, D. C., Byrd-Craven, J., Hoard, M. K., Vigil, J., and Numtee, C. (2003). Evolution and development of boys' social behavior. Dev. Rev. 23, 444-470.

Greenwald, A. G., McGhee, D. E., and Schwarz, J. L. K. (1998). Measuring individual differences in implicit cognition: the Implicit Association Test. J. Pers. Soc. Psychol. 74, 1464-1480.

Greenwald,A. G., Nosek, B.A., and Banaji, M. R. (2003). Understanding and using the Implicit Association Test: I. An improved scoring algorithm. J. Pers. Soc. Psychol. 85, 197-216.

Griskevicius, V., Tybur, J. M., Gangestad, S. W., Perea, E. F., Shapiro, J. R., and Kenrick, D. T. (2009). Aggress to impress: hostility as an evolved context-dependent strategy. J. Pers. Soc. Psychol. 96, 980-994.

Hewstone, M., Rubin, M., and Willis, H. (2002). Intergroup bias. Annu. Rev. Psychol. 53, 575-604.

Karpinski, A., and Hilton, J. L. (2001). Attitudes and the Implicit Association Test. J. Pers. Soc. Psychol. 81, 774-778.

Kurzban, R., and Leary, M. R. (2001). Evolutionary origins of stigmatization: the functions of social exclusion. Psychol. Bull. 127, 187-208.

Klavina, L., Buunk, A. P., and Park, J. H. (2009). "Intergroup jealousy: effects of perceived group characteristics and intrasexual competition between groups," in Human Characteristics: Evolutionary Perspectives on Human Mind and Kind, eds H. Hogh-Olesen, J. Tonnesvang, and P. Bertelsen (Newcastle: Cambridge Scholars Publishing), 382-397.

Letendre, K., Fincher, C. L., and Thornhill, R. (2010). Does infectious disease cause global variation in the frequency of intrastate armed conflict and civil war? Biol. Rev. 85, 669-683.

LeVine, R. A., and Campbell, D. T. (1972). Ethnocentrism: Theories of Conflict,
Ethnic Attitudes and Group Behavior. New York: Wiley.

Low, B. S. (1990). Marriage systems and pathogen stress in human societies. Am. Zool. 30, 325-339.

McCullough (2009). Denmark to Immigrants... here's 20K Dollars... now please leave, Weblog post. Available at: http://www.dvorak. org/blog/ 2009/11/14/denmark-toimmigrants-heres-20k-dollars-nowplease-leave/

Navarrete, C. D., and Fessler, D. M. T. (2006). Disease avoidance and ethnocentrism: the effects of disease vulnerability and disgust sensitivity on intergroup attitudes. Evol. Hum. Behav. 27, 270-282.

Navarrete, C. D., McDonald, M. M., Molina, L. E., and Sidanius, J. (2010). Prejudice at the nexus of race and gender: an outgroup male target hypothesis. J. Pers. Soc. Psychol. 98, 933-945.

Navarrete, C. D., Olsson, A., Ho, A., Mendes, W., Thomsen, L., and Sidanius, J. (2009). Fear extinction to an outgroup face: the role of target gender. Psychol. Sci. 20, 155-158.

Neuberg, S., and Cottrell, C. (2008). Managing the threats and opportunities afforded by human sociality. Group Dyn. 12, 63-72.

Palmer, C. T., and Tilley, C. F. (1995). Sexual access to females as a motivation for joining gangs: an evolutionary approach. J. Sex Res. 32, 213-217.

Park, J. H., Faulkner, J., and Schaller, M. (2003). Evolved disease-avoidance processes and contemporary anti-social behavior: prejudicial attitudes and avoidance of people with physical disabilities. J. Nonverbal Behav. 27, 65-87.

Park, J. H., Schaller, M., and Crandall, C. S. (2007). Pathogen-avoidance mechanisms and The stigmatization of obese people. Evol. Hum. Behav. 28, 410-414. 217.

Pratto, F., Sidanius, J., Stallworth, L. M., and Malle, B. F. (1994). Social dominance orientation: a personality variable predicting social and political attitudes. $J$. Pers. Soc. Psychol. 67, 741-763.
Schaller, M., Park, J. H., and Faulkner, J. (2003a). Prehistoric dangers and contemporary prejudices. Eur. Rev Soc. Psychol. 14, 105-137.

Schaller, M., Park, J. H., and Mueller, A. (2003b). Fear of the dark: interactive effects of beliefs about danger and ambient darkness on ethnic stereotypes. Pers. Soc. Psychol. Bull. 29, 637-649.

Schnabel, K., Asendorpf, J. B., and Greenwald, A. G. (2008). Assessment of individual differences in implicit cognition: a review of IAT measures. Eur. J. Psychol. Assess. 24, 210-217.

Sherif, M., Harvey, O. J., White, B. J. Hood, W. R., and Sherif, C. W. (1961). Intergroup Conflict and Cooperation: The Robbers Cave Experiment. Classics in The History of Psychology. Available at: http://psychclassics.yorku.ca/ Sherif/ [accessed March 27, 2009].

Sidanius, J., and Pratto, F. (1999). Social Dominance: An Intergroup Theory of Social Hierarchy and Oppression. New York: Cambridge University Press.

Stephan, W. G., Ybarra, O., Martinez, C. M., Schwarzwald, J., and Tur-Kaspa, M. (1998). Prejudice toward immigrants in Spain and Israel: an integrated threat theory analysis. J. Cross Cult. Psychol. 29, 559-576.

Symons, D. (1979). The Evolution of Human Sexuality. Oxford: Oxford University Press.

Tajfel, H., and Turner, J. C. (1979). “An integrative theory of intergroup conflict," in The Social Psychology of Intergroup Relations, eds W. G. Austin and S. Worchel (Monterey, CA: Brooks/Cole), 33-47.

Tooby, J., and Cosmides, L. (1988). The Evolution of War and Its Cognitive Foundations (Institute for Evolutionary Studies Tech. Rep. No. 88-1). Palo Alto, CA: Institute for Evolutionary Studies.

Trivers, R. L. (1972). "Parental investment and sexual selection," in Sexual Selection and The Descent of Man, ed. B. Campbell 1871-1971 (Chicago, IL: Aldine), 136-179.
Van Vugt, M. (2009). Sex differences in intergroup competition, aggression, and warfare: the male warrior hypothesis. Ann. N. Y. Acad. Sci. 1167, 124-134.

Van Vugt, M., De Cremer, D., and Janssen, D. (2007). Gender differences in competition and cooperation: the male warrior hypothesis. Psychol. Sci. 18, 19-23.

Van Vugt, M., and Park, J.H. (2009). Guns, germs, and sex: how evolution shaped our intergroup psychology. Soc. Pers. Psychol. Compass 3, 927-938.

Wrangham, R. (1999). Evolution of coalitionary killing. Yearb. Phys. Anthropol. 42, 1-30.

Wrangham, R., and Peterson, D. (1996). Demonic Males: Apes and the Origins of Human Violence. London: Bloomsbury.

Yuki, M., and Yokota, K. (2009). The primal warrior: outgroup threat priming enhances intergroup discrimination in men but not women. J. Exp. Soc. Psychol. 45, 271-274.

Conflict of Interest Statement: The authors declare that the research was conducted in the absence of any commercial or financial relationships that could be construed as a potential conflict of interest.

Received: 12 October 2010; accepted: 11 April 2011; published online: 04 May 2011. Citation: Klavina L, Buunk AP and Pollet TV (2011) Out-group mating threat and disease threat increase implicit negative attitudes toward the out-group among men. Front. Psychology 2:76. doi: 10.3389/ fpsyg.2011.00076

This article was submitted to Frontiers in Evolutionary Psychology, a specialty of Frontiers in Psychology.

Copyright (c) 2011 Klavina, Buunk and Pollet. This is an open-access article subject to a non-exclusive license between the authors and Frontiers Media SA, which permits use, distribution and reproduction in other forums, provided the original authors and source are credited and other Frontiers conditions are complied with. 


\section{APPENDIX}

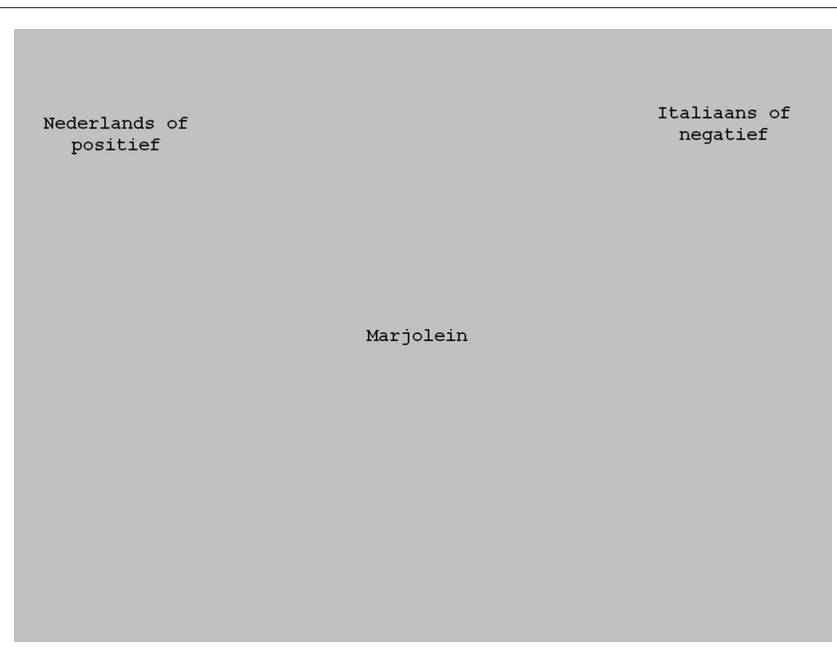

Table A1 | The stimuli words used in the IAT task.

\begin{tabular}{|c|c|c|c|c|c|}
\hline \multicolumn{2}{|c|}{ Italian } & \multicolumn{2}{|c|}{ Dutch } & \multirow{2}{*}{ Positive } & \multirow{2}{*}{ Negative } \\
\hline Male & Female & Male & Female & & \\
\hline Marcello & Francesca & Jan Pieter & Willemien & $\begin{array}{l}\text { vrijheid } \\
\text { (freedom) }\end{array}$ & $\begin{array}{l}\text { haat } \\
\text { (hate) }\end{array}$ \\
\hline Giovanni & Giovanna & Gerrit Jan & Marjolein & $\begin{array}{l}\text { liefde } \\
\text { (love) }\end{array}$ & $\begin{array}{l}\text { dood } \\
\text { (death) }\end{array}$ \\
\hline Luciano & Luciana & Martijn & Karlijn & $\begin{array}{l}\text { pret } \\
\text { (joy) }\end{array}$ & $\begin{array}{l}\text { oorlog } \\
\text { (war) }\end{array}$ \\
\hline Alesio & Biaggia & Jeroen & Femke & $\begin{array}{l}\text { vrede } \\
\text { (peace) }\end{array}$ & $\begin{array}{l}\text { pijn } \\
\text { (pain) }\end{array}$ \\
\hline Piero & Gianna & Henk & Loes & $\begin{array}{l}\text { geluk } \\
\text { (happiness) }\end{array}$ & $\begin{array}{l}\text { moord } \\
\text { (murder) }\end{array}$ \\
\hline
\end{tabular}

Figure A1 |A screenshot of the IAT task. 